\title{
STUDI FAKTOR-FAKTOR KETERLAMBATAN PROYEK PADA KONTRAKTOR DI DAERAH ISTIMEWA YOGYAKARTA
}

\author{
Farlianto, MBA \\ Email: farlianto@uny.ac.id
}

Manajemen FE, UNY, Yogyakarta

\begin{abstract}
This study is aimed to investigate the antecedent of the project deleyed of contractors work. Various antecedent are explored both partially and simultanously. Sample are gathered from the site managers of Dinas Pengairan dan Dinas Bina Marga for DIY project. The result shows that a lot of antecedent such as work document aspect, inspection system, job control and evaluation, organizational system, Coordination and communication, other uncontrolable aspect, the readiness of resourches, and the work planning and schedulling aspect are related to the deleyed of project. The implication of the results are discussed.
\end{abstract}

Keywords: antecedent, project deleyed, contractors

Pendahuluan

Pada era globalisasi dan pasar bebas hanya perusahaan yang mampu melakukan perbaikan terus-menerus (continuous improvement) dalam pembentukan keunggulan kompetitif yang mampu untuk berkembang. Organisasi sekarang harus dilandasi oleh keluwesan, team kerja yang baik, kepercayaan, dan penyebaran informasi yang memadai. Salah satu upaya yang dapat ditempuh dalam menghadapi situasi ini adalah menentukan kualitas kerja organisasi, dimana pihak manajemen perlu memperhatikan proses produksi dan menciptakan keunggulan bersaing melalui kesuksesan proyek. Perusahaan merupakan kesatuan unit bisnis yang diharapkan mampu memberikan laba atau keuntungan bagi perusahaan. Pada umumnya suatu perusahaan harus mampu mencapai tingkat efektivitas dan efisiensi setinggi mungkin dalam menjalankan kegiatan operasionalnya tanpa harus meninggalkan kualitas dan kuantitas produk. Untuk mengetahui berhasil tidaknya kegiatan operasional perusahaan diperlukan adanya penganalisaan sumber dan penjadwalan kerja sebagai bahan pertimbangan untuk perencanaan operasional perusahaan. 
Kesuksesan

organisasi

tergantung pada kinerja karyawan dalam penyelesaian tugas-tugas untuk mencapai tujuan organisasi.

Keberhasilan perusahaan dalam mencapai tujuannya tidak dapat dilepaskan dari peran perencanaan kerja dan penjadwalan kerja. Setiap proyek konstruksi lazimnya mempunyai rencana pelaksanaan dan jadwal pelaksanaan yang tertentu, kapan pelaksanaan proyek tersebut harus dimulai, kapan harus diselesaikan dan bagaimana proyek tersebut akan dikerjakan, serta bagaimana penyediaan sumber dayanya. Dalam manajemen proyek, perencanaan menempati urutan pertama dari fungsi manajemen. Dari segi penggunaan sumber daya, perencanaan dapat diartikan sebagai pemberi pegangan bagi pelaksana mengenai alokasi sumber daya untuk melaksanakan kegiatan dan memastikan penggunaan sumber daya secara efektif dan efisien (Soeharto, 1995). Dalam perencanaan kerja seringkali timbul masalah-masalah operasional yang menghambat aktivitas penyelesaian suatu proyek seperti kurangnya sumber daya, alokasi sumber daya yang tidak tepat, keterlambatan pelaksanaan proyek, dan masalah-masalah lainnya diluar jadwal dalam rencana kerja (Nicholas, 1990).

Pembuatan rencana dan jadwal pelaksanaan selalu mengacu pada kondisi anggapan-anggapan dan prakiraan yang ada pada saat rencana dan jadwal tersebut dibuat, karena itu masalah akan timbul apabila terjadi ketidak sesuaian antara prakiraan dan anggapan dengan kenyataan yang sebenarnya. Dampak umum yang sering terjadi adalah keterlambatan waktu pelaksanaan proyek, disamping peningkatannya biaya pelaksanaan proyek. Keterlambatan pelaksanaan proyek umumnya selalu menimbulkan akibat yang merugikan baik bagi pemilik maupun kontraktor, karena dampak keterlambatan adalah konflik dan perdebatan tentang apa dan siapa yang menjadi penyebab, juga tuntutan waktu dan biaya tambah. Perusahaan perlu memperhatikan manajemen proyek khususnya mengenai kegiatan proses produksi yang bisa didekati dengan identifikasi faktor-faktor yang menyebabkan keterlambatan proyek. Suatu proses produksi yang memang perlu mendapat perhatian serius karena keterlambatan kegiatan di jalur 
kritis kan menyebabkan keterlambatan proyek secara keseluruhan. Penelitian dalam temuan faktor-faktor yang menyebabkan keterlambatan diharapkan dapat menjadi rujukkan bagi pemilik atau kontraktor untuk menyusun perencanaan dan penjadwalan proyek yang lebih seksama, sebagai upaya awal untuk menghindari dan atau mengendalikan keterlambatan waktu pelaksanaan proyek.

Penelitian mengenai faktor-faktor keterlambatan proyek pernah dilakukan oleh Elinwa dan Buba (1993), Kaming (1996), Scoots (1997) dan Proboyo (1999). Penelitian ini bertujuan mengidentifikasi faktorfaktor yang menyebabkan keterlambatan proyek pada kontraktor khususnya di Yogyakarta. Dengan demikian penelitian ini penulis beri judul "Studi Faktor-Faktor Keterlambatan Proyek Pada Kontraktor di Daerah Istimewa Yogyakarta".

Dalam pembangunan suatu proyek sering terjadi masalah, seperti terdapatnya permasalahan material, tenaga kerja , kualitas serta dana yang dapat menyebabkan keterlambatan suatu proyek. Berdasarkan alasan- alasan di atas dalam masalah penelitian ini dirumuskan sebagai berikut:

1. Apakah faktor-faktor yang menyebabkan keterlambatan waktu pelaksanaan proyek yaitu aspek perencanaan dan penjadwalan pekerjaan, aspek lingkungan dan dokumen pekerjaan, aspek sistem organisasi, koordinasi dan komunikasi, aspek kesiapan/penyiapan sumber daya, aspek sistem inspeksi, aspek kontrol dan evaluasi pekerjaan dan aspek lain-lainnya diluar kontrol pemilik di lingkungan Perusahaan kontraktor DIY berpengaruh secara simultan terhadap terhadap keterlambatan proyek?

2. Apakah faktor-faktor yang menyebabkan keterlambatan waktu pelaksanaan proyek yaitu aspek perencanaan dan penjadwalan pekerjaan, aspek lingkungan dan dokumen pekerjaan, aspek sistem organisasi, koordinasi dan komunikasi, aspek kesiapan/penyiapan sumber daya, aspek sistem inspeksi, aspek kontrol dan evaluasi pekerjaan dan aspek lain-lainnya diluar 
kontrol pemilik di lingkungan Perusahaan kontraktor DIY berpengaruh secara parsial terhadap terhadap keterlambatan proyek?

Penyebab Keterlambatan Proyek

Menurut Kraiem dan Dickmann (1987), penyebab-penyebab

keterlambatan waktu pelaksanaan proyek dapat dikatagorikan kedalam 3 kelompok besar yakni :

1. Keterlambatan yang layak mendapatkan ganti rugi (Compensable Delay), yakni keterlambatan yang disebabkan oleh tindakan kelalaian atau kesalahan pemilik proyek.

2. Keterlambatan yang tidak dapat dimanfaatkan (Non-Excusable Delay), yakni keterlambatan yang disebabkan oleh tindakan, kelalaian atau kesalahan pemilik proyek.

3. Keterlambatan yang dapat dimanfaatkan (Excusable Delay), yakni keterlambatan yang disebabkan oleh kejadian-kejadian diluar kendali baik pemilik maupun kontraktor.

Proses manajemen itu bertujuan mencapai sasaran dengan menjalankan fungsi-fungsi manajemen dan mendayagunakan sumber daya yang tersedia. Pada proyek kontruksi, penerapan fungsi-fungsi manajemen (planning, organizing, staffing, leading, controlling) dalam pelaksanaan proyek adalah hal yang penting untuk menunjang keberhasilan proyek. Temuan 45 jenis penyebab keterlambatan yang telah dikelompokkan dalam 3 kategori, dengan demikian perlu juga diklasifikasikan keberadaannya dalam aspek manajemen yang akan di tinjau. Untuk keperluan penelitian ini diambil 6 aspek kajian, yakni :

a. Aspek Perencanaan dan Penjadwalan pekerjaan $=6$ jenis penyebab.

b. Aspek Lingkup dan Dokumen Pekerjaan $=8$ jenis penyebab .

c. Aspek sistem Organisasi, Koordinasi dan Komunikasi $=9$ jenis penyebab.

d. Aspek Kesiapan/Penyiapan Sumber Daya $=8$ jenis penyebab.

e. Aspek Sistem Inspeksi, Kontrol dan Evaluasi Pekerjaan $=7$ jenis penyebab

f. Aspek Lain-lain $=7$ jenis penyebab.

Matriks hubungan antara ke 45 jenis penyebab keterlambatan, 6 aspek 
manajemen penyebab keterlambatan proyek dapat dilihat pada Tabel 1.

\begin{tabular}{|c|c|}
\hline No. & $\begin{array}{c}\text { Tinjauan Aspek dan Sebab } \\
\text { Keterlambatan }\end{array}$ \\
\hline A. & Aspek Perencanaan \& Penjadwalan \\
\hline 1. & $\begin{array}{l}\text { Penetapan jadwal proyek yang amat } \\
\text { ketat oleh pemilik }\end{array}$ \\
\hline 2. & $\begin{array}{l}\text { Tidak lengkapnya identifikasi jenis } \\
\text { pekerjaan yang harus ada }\end{array}$ \\
\hline 3. & $\begin{array}{l}\text { Rencana urutan kerja yang tidak } \\
\text { tersusun dengan baik/terpadu }\end{array}$ \\
\hline 4. & $\begin{array}{l}\text { Penentuan durasi waktu kerja yang } \\
\text { tidak seksama }\end{array}$ \\
\hline 5. & $\begin{array}{l}\text { Rencana kerja pemilik yang sering } \\
\text { berubah-ubah }\end{array}$ \\
\hline 6. & $\begin{array}{l}\text { Metode konstruksi/pelaksanaan kerja } \\
\text { yang salah atau tidak tepat }\end{array}$ \\
\hline B. & $\begin{array}{l}\text { Aspek Lingkungan dan Dokumen } \\
\text { Pekerjaan (Kontrak) }\end{array}$ \\
\hline 1. & $\begin{array}{l}\text { Perencanaan (gambar/spesifikasi) yang } \\
\text { salah/tidak lengkap }\end{array}$ \\
\hline 2. & $\begin{array}{l}\text { Perubahan disain/detail pekerjaan pada } \\
\text { waktu pelaksanaan }\end{array}$ \\
\hline 3. & $\begin{array}{l}\text { Perubahan lingkup pekerjaan pada } \\
\text { waktu pelaksanaan }\end{array}$ \\
\hline 4. & $\begin{array}{l}\text { Proses pembuatan gambar kerja oleh } \\
\text { kontraktor }\end{array}$ \\
\hline 5. & $\begin{array}{l}\text { Proses permintaan dan persetujuan } \\
\text { gambar kerja oleh pemilik }\end{array}$ \\
\hline 6. & $\begin{array}{l}\text { Ketidaksepahaman aturan pembuatan } \\
\text { gambar kerja }\end{array}$ \\
\hline 7. & $\begin{array}{l}\text { Adanya banyak (sering) pekerjaan } \\
\text { tambah }\end{array}$ \\
\hline 8. & $\begin{array}{l}\text { Adanya permintaan perubahan atas } \\
\text { pekerjaan yang telah selesai }\end{array}$ \\
\hline C. & $\begin{array}{l}\text { Aspek Sistem Organisasi, Koordinasi } \\
\text { dan Komunikasi }\end{array}$ \\
\hline 1. & $\begin{array}{l}\text { Keterbatasan wewenang personil } \\
\text { pemilik alam pengambilan keputusan }\end{array}$ \\
\hline 2. & $\begin{array}{l}\text { Kualifikasi personil/pemilik yang tidak } \\
\text { profesional di bidangnya }\end{array}$ \\
\hline 3. & $\begin{array}{l}\text { Cara inspeksi dan kontrol pekerjaan } \\
\text { yang birokrasi oleh pemilik }\end{array}$ \\
\hline 4. & $\begin{array}{l}\text { Kegagalan pemilik mengkoordinasi } \\
\text { pekerjaan dari banyak kontraktor/sub } \\
\text { Kontraktor. }\end{array}$ \\
\hline 5 & $\begin{array}{l}\text { Kegagalan pemilik mengkoordinasi } \\
\text { penyerahaan/pengunaan lahan }\end{array}$ \\
\hline 6 & $\begin{array}{l}\text { Kelambatan penyediaan alat/bahan dll. } \\
\text { yang disediakan pemilik }\end{array}$ \\
\hline 7 & $\begin{array}{l}\text { Kualifikasi teknis dan manajerial yang } \\
\text { buruk dari personil-personil dalam } \\
\text { organisasi kerja kontraktor }\end{array}$ \\
\hline
\end{tabular}

\begin{tabular}{|c|l|}
\hline 8 & $\begin{array}{l}\text { Koordinasi dan komunikasi yang buruk } \\
\text { antar bagian-bagian dalam organisasi } \\
\text { kerja kontraktor }\end{array}$ \\
\hline 9. & Terjadinya kecelakaan kerja \\
\hline
\end{tabular}

\begin{tabular}{|c|c|}
\hline $\mathrm{D}$ & $\begin{array}{l}\text { Aspek Kesiapan/Penyiapan } \\
\text { Sumber Daya }\end{array}$ \\
\hline 1. & $\begin{array}{l}\text { Mobilisasi Sumber Daya (bahan, } \\
\text { alat tenaga kerja) yang lambat }\end{array}$ \\
\hline 2. & $\begin{array}{l}\text { Kurangnya keahlian dan } \\
\text { keterampilan serta motivasi kerja } \\
\text { para pekerja-pekerja langsung di } \\
\text { tapak }\end{array}$ \\
\hline 3. & $\begin{array}{l}\text { Jumlah pekerja yang kurang } \\
\text { mamadai/sesuai dengan aktivitas } \\
\text { pekerjaan yang ada }\end{array}$ \\
\hline
\end{tabular}

4. Tidak tersedianya bahan secara cukup pasti/layak sesuai kebutuhan

5. Tidak tesedianya alat/peralatan yang cukup memadai/ sesuai kebutuhan

6. Kelalaian/keterlambatan oleh sub kontraktor pekerjaan

7. Pendanaan kegiatan proyek yang tidak terencana dengan baik (kesulitan pendanaan di kontraktor)

8. Tidak terbanyarnya kontraktor secara layak sesuai haknya (kesulitan pembayaran oleh pemilik)

E. Aspek Sistem inspeksi, Kontrol dan Evaluasi Pekerjaan

1. Pengajuan bahan bahan oleh kontraktor yang tidak terjadwal

2. Proses permintaan dan persetujuan contoh bahan oleh pemilik yang lama

3. Proses pengujian dan evaluasi uji bahan dari pemilik yang tidak relevan

4. Proses persetujuan ijin kerja yang bertele-tele

5. Kegagalan kontraktor melaksanakan pekerjaan

6. Banyak hasil pekerjaan yang 


\begin{tabular}{|c|c|}
\hline & $\begin{array}{l}\text { arus diperbaiki/diulang karena } \\
\text { cat/tidak benar }\end{array}$ \\
\hline 7. & $\begin{array}{l}\text { Proses dan tata cara evaluasi } \\
\text { kemajuan pekerjaan yang lama } \\
\text { dan lewat jadwal yang disepakati }\end{array}$ \\
\hline F. & $\begin{array}{l}\text { Aspek Lain-lain (Aspek diluar } \\
\text { kemampuan Pemilik dan } \\
\text { Kontraktor) }\end{array}$ \\
\hline 1. & $\begin{array}{l}\text { Kondisi dan lingkungan tanpak } \\
\text { nyata tidak sesuai dengan dugaan }\end{array}$ \\
\hline 2. & $\begin{array}{l}\text { Trasportasi ke lokasi proyek yang } \\
\text { sulit }\end{array}$ \\
\hline 3. & $\begin{array}{l}\text { Terjadinya hal-hal tak terduga } \\
\text { seperti kebakaran, banjir, } \\
\text { badai/angin ribut, gempa bumi, } \\
\text { tanah longsor dan cuaca amat } \\
\text { buruk }\end{array}$ \\
\hline 4. & Adanya kemogokan buruh \\
\hline 5. & $\begin{array}{l}\text { Adanya huru/hara kerusuhan } \\
\text { perang }\end{array}$ \\
\hline 6. & $\begin{array}{l}\text { Terjadinya } \\
\text { kerusakan/pengrusakan akibat } \\
\text { kelalaian atau perbuatan pihak } \\
\text { ketiga }\end{array}$ \\
\hline 7. & $\begin{array}{ll}\text { Perubahan } & \text { situasi atau } \\
\text { kebijaksanaan } & \text { politik/ekonomi } \\
\text { pemerintah } & \end{array}$ \\
\hline
\end{tabular}

Sumber : Arditi dan Gurdaman (1) ; Arditi dan Patel (3); Elinwa dan Buba (6); Kaming (7); Krajem dan Dickmann (8); Scott (9)

Keberhasilan suatu proyek dikaitkan sejauhmana sasaran jadwal, mutu dan anggaran yang terpenuhi. Pengukuran tercapainya anggaran yang efektif dengan biaya yang efisien, pengukuran jadwal yang efektif dengan waktu yang tepat dan singkat serta pengukuran mutu yang efektif dengan tercapainya kinerja dengan baik (Soeharto, 1995). Kesuksesan proyek dapat dilihat dari tiga aspek dalam pelaksanaan suatu proyek. Aspek keberhasilan proyek dapat dilihat dari (Soeharto, 1999):

1. Mutu (Quality) menunjukkan hasil yang sesuai standar

2. Waktu (Time) menunjukkan waktu yang efisien dan efektif

3. Biaya (Cost) menunjukkan biaya yang efisien dan efektif

\section{Hipotesis}

H1: Faktor-faktor yang menyebabkan keterlambatan waktu pelaksanaan proyek yaitu aspek perencanaan dan penjadwalan pekerjaan, aspek lingkungan dan dokumen pekerjaan, aspek sistem organisasi, koordinasi dan komunikasi, aspek kesiapan/penyiapan sumber daya, aspek sistem inspeksi, aspek kontrol dan evaluasi pekerjaan dan aspek lain-lainnya diluar kontrol pemilik di lingkungan Perusahaan kontraktor DIY berpengaruh secara simultan terhadap terhadap keterlambatan proyek

H2: Faktor-faktor yang menyebabkan keterlambatan waktu pelaksanaan proyek yaitu aspek perencanaan 
dan penjadwalan pekerjaan, aspek lingkungan dan dokumen pekerjaan, aspek sistem organisasi, koordinasi dan komunikasi, aspek kesiapan/penyiapan sumber daya, aspek sistem inspeksi, aspek kontrol dan evaluasi pekerjaan dan aspek lain-lainnya diluar kontrol pemilik di lingkungan Perusahaan kontraktor DIY berpengaruh secara parsial terhadap terhadap keterlambatan proyek

\section{Metode Penelitian}

Jenis penelitian ini merupakan penelitian survey dengan menggunakan kuesioner yang disebarkan kepada kontraktor di Yogyakarta khususnya kontraktor di bidang pengairan dan jasa marga di DIY.

\section{Populasi dan Sampel}

Populasi yang akan diteliti adalah kontraktor di DIY di lingkungan Perusahaan kontraktor DIY dengan bidang Pengairan dan bidang Bina Marga. Sampel penelitian diambil dengan metode purposive sampling dengan kriteria jenis kontraktor utama dan diketahui sebanyak 51 kontraktor kelas utama di DIY.

Analisis Data

Responden dalam penelitian ini dapat dikategorikan dalam beberapa karakteristik responden yaitu berdasarkan usia, pendidikan terakhir, lama pengalaman kerja sebagai site manajer, dan pengalaman kerja keseluruhan. Jumlah kuesioner yang disebar sebanyak 51 kuesioner. Kuesioner yang kembali sebanyak 51 kuesioner. Total responden dalam penelitian ini berjumlah 51 orang site manajer yang terdiri dari site manajer Dinas Pengairan dan Dinas Bina Marga di lingkungan Perusahaan kontraktor DIY yang termasuk dalam golongan utama. Uraian berikut ini merupakan penjelasan karakteristik demografis responden tersebut.

\section{Komposisi}

responden berdasarkan usia adalah sebagai berikut:

Tabel 1. Karakteristik Responden Berdasarkan Usia

\begin{tabular}{|c|c|c|}
\hline $\begin{array}{c}\text { Usia } \\
\text { (tahun) }\end{array}$ & Jumlah & Persentase \\
\hline$<30$ & 4 & $7,80 \%$ \\
\hline $30-35$ & 13 & $25,50 \%$ \\
\hline $36-41$ & 22 & $43,20 \%$ \\
\hline$>41$ & 12 & $23,50 \%$ \\
\hline Total & 51 & $100 \%$ \\
\hline \multicolumn{3}{|c|}{ Sumber: Data Primer } \\
\hline
\end{tabular}


Dari tabel di atas dapat diidentifikasi bahwa komposisi usia responden dalam penelitian ini yaitu responden yang berusia $\leq 29$ tahun berjumlah 4 orang $(5,48 \%)$, yang berusia 30-35 tahun berjumlah 13 orang $(17,81 \%)$, yang berusia $36-41$ tahun berjumlah 39 orang $(53,42 \%)$, dan yang berusia $>41$ tahun berjumlah 17 orang (23,29\%). Dengan demikian, mayoritas konsumen dalam penelitian ini berusia 31-40 tahun. Hal ini menunjukkan mayoritas manajer proyek berusia 36-41 tahun.

Komposisi

responden

berdasarkan pendidikan terakhir secara rinci diperlihatkan dalam tabel di bawah ini:

Tabel 2 Karakteristik Responden Berdasarkan Pendidikan Terakhir

\begin{tabular}{|c|c|c|}
\hline Pendidikan & Jumlah & Persentase \\
\hline SLTA/STM & 12 & $23,50 \%$ \\
\hline D3 & 11 & $21,60 \%$ \\
\hline S1 & 28 & $54,90 \%$ \\
\hline Jumlah & 51 & $100 \%$ \\
\hline
\end{tabular}

Sumber: Data Primer

Dari tabel dapat diidentifikasi bahwa komposisi pendidikan responden dalam penelitian ini yaitu pendidikan SLTA/STM sebanyak 12 orang atau 23,50\%, yang berpendidikan D3 sebanyak 11 orang atau $21,60 \%$, yang berpendidikan S1 sebanyak 28 orang atau $54,90 \%$. Dengan demikian mayoritas site manajer dalam penelitian ini berpendidikan sarjana/strata satu.

$$
\text { Komposisi responden }
$$

berdasarkan lama pengalaman kerja sebagai Site manajer secara rinci diperlihatkan dalam tabel di bawah ini:

\section{Tabel 3 Karakteristik Responden} Berdasarkan Lama Pengalaman Kerja Sebagai Site Manajer

\begin{tabular}{|c|c|c|}
\hline $\begin{array}{c}\text { Pengalaman } \\
\text { Kerja }\end{array}$ & Jumlah & Persentase \\
\hline$<5$ tahun & 11 & $21,60 \%$ \\
\hline $6-10$ tahun & 25 & $49,00 \%$ \\
\hline $11-20$ tahun & 10 & $19,60 \%$ \\
\hline$>20$ tahun & 5 & $9,80 \%$ \\
\hline Jumlah & 51 & $100 \%$ \\
\hline \multicolumn{3}{|c|}{ Sumber: Data Primer, 2015.}
\end{tabular}

Dari tabel di atas dapat diidentifikasi bahwa responden yang memiliki pengalaman kerja sebagai site manajer < 5 tahun sebanyak 11 orang atau $21,60 \%$, responden yang memiliki pengalaman kerja sebagai site manajer 6-10 tahun sebanyak 25 orang atau 49,00\%, yang memiliki pengalaman kerja sebagai site manajer 11-20 tahun sebanyak 10 orang atau $19,60 \%$ dan yang memiliki pengalaman kerja sebagai site manajer $>20$ tahun sebanyak 5 orang atau $9,80 \%$. Dengan demikian mayoritas 
site manajer dalam penelitian ini memiliki pengalaman kerja sebagai site manajer selama 6-10 tahun.

Uji Validitas dan Reliabilitas

Berdasarkan hasil pengujian validitas atas butir instrumen penelitian yang menunjukkan bahwa dari 51 responden yang dijadikan sampel dalam penelitian ini, terlihat bahwa aitem untuk semua variabel valid atau sah karena memiliki nilai $\mathrm{r}$ korelasi di atas 0,30 .

Uji reliabilitas butir pertanyaan dalam kuesioner dilakukan dengan tujuan untuk menguji konsistensi derajat ketergantungan dan stabilitas dari alat ukur. Sedangkan menurut Ghozali (2006 : 133) yang mengemukakan bahwa butir pertanyaan dalam kuesioner dikatakan reliabel jika nilai cronbach's alpa $>0,60$. Dari hasil uji reliabilitas butir pertanyaan dengan program statistik SPSS versi 17 diperoleh dari hasil cronbach's alpha yang lebih besar dari 0,60 untuk kedua variabel yang diuji sudah reliabel atau handal.

Hasil regresi linier berganda pengaruh faktor-faktor katerlambatan proyek terhadap keterlambatan proyek di lingkungan Perusahaan kontraktor DIY bidang Pengairan dan jasa marga sebagai berikut :

Tabel 4. Hasil Regresi Linier Berganda di Bidang Pengairan dan Jasa Marga

\begin{tabular}{|c|c|c|c|}
\hline Keterangan & B & $\mathrm{t}$ & Sig. \\
\hline (Constant) & 5.230 & 40.225 & 0.000 \\
\hline Aspek perencanaan dan & & & \\
\hline penjadwalan pekerjaan & -0.163 & -3.291 & 0.005 \\
\hline Aspek lingkup dan & & & \\
\hline dokumen pekerjaan & $-0,044$ & -3.468 & 0.005 \\
\hline Aspek sistem organisasi, & & & \\
\hline koordinasi dan & & & \\
\hline komunikasi & $-0,002$ & -3.048 & 0.002 \\
\hline Aspek & & & \\
\hline kesiapan/penyiapan & & & \\
\hline sumber daya & -0.171 & -2.530 & 0.022 \\
\hline Aspek sistem inspeksi, & & & \\
\hline aspek kontrol dan & & & \\
\hline evaluasi pekerjaan & -0.105 & -2.150 & 0.027 \\
\hline Aspek lain-lainnya & & & \\
\hline diluar kontrol pemilik & -0.240 & -3.854 & 0.001 \\
\hline
\end{tabular}

Sumber: Data Primer.

Dari persamaan regresi tersebut dapat dilihat bahwa aspek perencanaan dan penjadwalan pekerjaan memiliki koefisien sebesar yaitu -0,163 yang berarti besarnya kontribusi faktor aspek perencanaan 
dan penjadwalan pekerjaan terhadap perubahan keterlambatan proyek sebesar $-0,163$ atau 16,3\%, aspek lingkup dan dokumen pekerjaan memiliki koefisien sebesar -0,044 yang berarti besarnya kontribusi aspek lingkup dan dokumen pekerjaan terhadap perubahan keterlambatan proyek sebesar -0,044 atau 4,4\%. Aspek sistem organisasi, koordinasi dan komunikasi memiliki koefisien sebesar - 0.002 yang berarti besarnya kontribusi aspek sistem organisasi, koordinasi dan komunikasi terhadap perubahan keterlambatan proyek sebesar -0,002 atau 0,2\%. Aspek kesiapan/penyiapan sumber daya memiliki koefisien sebesar -0.171 yang berarti besarnya kontribusi aspek kesiapan/penyiapan sumber daya terhadap perubahan keterlambatan proyek sebesar --0,171 atau $17,1 \%$. Aspek sistem inspeksi, aspek kontrol dan evaluasi pekerjaan memiliki koefisien sebesar -0,105 yang berarti besarnya kontribusi aspek sistem inspeksi, aspek kontrol dan evaluasi pekerjaan terhadap perubahan keterlambatan proyek sebesar -0,105 atau $10,5 \%$. Aspek lain-lainnya diluar kontrol pemilik memiliki koefisien sebesar -0,240 yang berarti besarnya kontribusi aspek lain-lainnya diluar kontrol pemilik terhadap perubahan keterlambatan proyek sebesar $-0,240$ atau $24,0 \%$. Hubungan negatif tiap faktor menunjukkan apabila semakin tinggi faktor keterlambatan proyek maka semakin rendah tingkat keterlambatan proyek. Sebaliknya semakin rendah faktor keterlambatan proyek maka semakin tinggi tingkat keterlambatan proyek Nilai konstanta sebesar 5,230 menunjukkan bahwa meskipun tidak ada faktor keterlambatan proyek, proyek tetap memiliki keterlambatan sebesar 5,230.

Besarnya nilai pengaruh faktorfaktor keterlambatan proyek secara simultan ditunjukkan oleh nilai koefisien determinasi (R2) $=98,3 \%$ yaitu persentase pengaruh faktorfaktor keterlambatan proyek yang terdiri dari aspek perencanaan dan penjadwalan pekerjaan, aspek lingkup dan dokumen pekerjaan, aspek sistem organisasi, koordinasi dan komunikasi, aspek kesiapan/penyiapan sumber daya, aspek sistem inspeksi, kontrol dan evaluasi dan aspek lain-lain diluar kendali pemilik terhadap perubahan tingkat keterlambatan proyek di dinas pengairan adalah sebesar $98,3 \%$. 
Variabel lain yang menjelaskan variasi perubahan tingkat keterlambatan proyek secara menyeluruh adalah sebesar $1,7 \%$.

Analisis pengaruh faktor-faktor keterlambatan proyek terhadap keterlambatan proyek di dinas pengairan lingkungan Perusahaan kontraktor DIY secara parsial sebagai berikut:

1. Pengujian terhadap koefisisen regresi aspek perencanaan dan penjadwalan pekerjaan, aspek lingkungan dan dokumen pekerjaan, aspek sistem organisasi, koordinasi dan komunikasi, aspek kesiapan/penyiapan sumber daya, aspek sistem inspeksi, aspek kontrol dan evaluasi pekerjaan dan aspek lain-lainnya diluar kontrol pemilik di lingkungan Perusahaan kontraktor DIY secara simultan. Untuk menguji pengaruh aspek perencanaan dan penjadwalan pekerjaan, aspek lingkungan dan dokumen pekerjaan, aspek sistem organisasi, koordinasi dan komunikasi, aspek kesiapan/penyiapan sumber daya, aspek sistem inspeksi, aspek kontrol dan evaluasi pekerjaan dan aspek lain-lainnya diluar kontrol pemilik di lingkungan Perusahaan kontraktor DIY secara simultan terhadap keterlambatan proyek dengan membandingkan F-hitung dengan probabilitas 0,000 lebih kecil dari 0,05 sehingga dapat disimpulkan bahwa aspek perencanaan dan penjadwalan pekerjaan, aspek lingkungan dan dokumen pekerjaan, aspek sistem organisasi, koordinasi dan komunikasi, aspek kesiapan/penyiapan sumber daya, aspek sistem inspeksi, aspek kontrol dan evaluasi pekerjaan dan aspek lain-lainnya diluar kontrol pemilik di lingkungan Perusahaan kontraktor DIY secara simultan berpengaruh terhadap keterlambatan proyek.

2. Pengujian terhadap koefisisen regresi aspek perencanaan dan penjadwalan pekerjaan. Pengujian secara statistik pengaruh aspek perencanaan dan penjadwalan pekerjaan terhadap keterlambatan proyek dengan cara membandingkan nilai t-hitung dengan nilai t-tabel. Dengan taraf signifikan sebesar 0,05 atau 5\%, pengujian dua sisi dan dk $(n=23)$ maka diperoleh ttabel $=2,069$. 
Untuk menguji pengaruh faktor perencanaan dan penjadwalan pekerjaan terhadap keterlambatan proyek dengan membandingkan thitung sebesar 3,291 dan ttabel 2,069 dengan probabilitas 0,005 lebih kecil dari 0,05 yang berarti thitung > ttabel, sehingga dapat disimpulkan bahwa faktor perencanaan dan penjadwalan pekerjaan secara parsial berpengaruh secara signifikan dan negatif terhadap keterlambatan proyek.

3. Pengujian terhadap koefisisen regresi aspek lingkup dan dokumen pekerjaan. Pengujian secara statistik pengaruh aspek lingkup dan dokumen pekerjaan terhadap keterlambatan proyek dengan cara membandingkan nilai t-hitung dengan nilai t-tabel. Dengan taraf signifikan sebesar 0,05 atau $5 \%$, pengujian dua sisi dan $\mathrm{dk}(\mathrm{n}=23)$ maka diperoleh ttabel $=2,069$. Untuk menguji pengaruh faktor lingkup dan dokumen pekerjaan terhadap keterlambatan proyek dengan membandingkan t-hitung sebesar 3,468 dan ttabel 2,069 dengan probabilitas 0,005 lebih kecil dari
0,05 yang berarti thitung > ttabel, sehingga dapat disimpulkan bahwa faktor lingkup dan dokumen pekerjaan secara parsial berpengaruh secara signifikan dan negatif terhadap keterlambatan proyek.

4. Pengujian terhadap koefisisen regresi aspek sistem organisasi, koordinasi dan komunikasi Pengujian secara statistik pengaruh aspek sistem organisasi, koordinasi dan komunikasi terhadap keterlambatan proyek dengan cara membandingkan nilai t-hitung dengan nilai t-tabel. Dengan taraf signifikan sebesar 0,05 atau $5 \%$, pengujian dua sisi dan $\mathrm{dk}(\mathrm{n}=23)$ maka diperoleh ttabel $=2,069$. Untuk menguji pengaruh faktor sistem organisasi, koordinasi dan komunikasi terhadap keterlambatan proyek dengan membandingkan t-hitung sebesar 3,048 dan ttabel 2,069 dengan probabilitas 0,002 lebih kecil dari 0,05 yang berarti thitung $>$ ttabel, sehingga dapat disimpulkan bahwa faktor sistem organisasi, koordinasi dan komunikasi secara parsial berpengaruh secara signifikan dan 
negatif terhadap keterlambatan proyek.

5. Pengujian terhadap koefisisen regresi aspek kesiapan/penyiapan sumber daya. Pengujian secara statistik pengaruh aspek kesiapan/penyiapan sumber daya terhadap keterlambatan proyek dengan cara membandingkan nilai t-hitung dengan nilai t-tabel. Dengan taraf signifikan sebesar 0,05 atau 5\%, pengujian dua sisi dan dk $(n=23)$ maka diperoleh ttabel $=2,069$. Untuk menguji pengaruh faktor kesiapan/penyiapan sumber daya terhadap keterlambatan proyek dengan membandingkan t-hitung sebesar 2,530 dan ttabel 2,069 dengan probabilitas 0,022 lebih kecil dari 0,05 yang berarti thitung $>$ ttabel, sehingga dapat disimpulkan bahwa aspek kesiapan/penyiapan sumber daya secara parsial berpengaruh secara signifikan dan negatif terhadap keterlambatan proyek.

6. Pengujian terhadap koefisisen regresi aspek sistem inspeksi, aspek kontrol dan evaluasi pekerjaan. Pengujian secara statistik pengaruh aspek sistem inspeksi, aspek kontrol dan evaluasi pekerjaan terhadap keterlambatan proyek dengan cara membandingkan nilai t-hitung dengan nilai t-tabel. Dengan taraf signifikan sebesar 0,05 atau 5\%, pengujian dua sisi dan dk $(n=23)$ maka diperoleh ttabel $=2,069$. Untuk menguji pengaruh faktor sistem inspeksi, aspek kontrol dan evaluasi pekerjaan terhadap keterlambatan proyek dengan membandingkan t-hitung sebesar 2,150 dan ttabel 2,069 dengan probabilitas 0,027 lebih kecil dari 0,05 yang berarti thitung > ttabel, sehingga dapat disimpulkan bahwa faktor sistem inspeksi, aspek kontrol dan evaluasi pekerjaan secara parsial berpengaruh secara signifikan dan negatif terhadap keterlambatan proyek.

7. Pengujian terhadap koefisisen regresi aspek lain-lainnya diluar kontrol pemilik. Pengujian secara statistik pengaruh aspek lainlainnya diluar kontrol pemilik terhadap keterlambatan proyek dengan cara membandingkan nilai t-hitung dengan nilai t-tabel. Dengan taraf signifikan sebesar 
0,05 atau 5\%, pengujian dua sisi dan $\mathrm{dk}(\mathrm{n}=23)$ maka diperoleh ttabel $=2,069$. Untuk menguji pengaruh faktor lain-lainnya diluar kontrol pemilik terhadap keterlambatan proyek dengan membandingkan t-hitung sebesar 3,854 dan ttabel 2,069 dengan probabilitas 0,001 lebih kecil dari 0,05 yang berarti thitung > ttabel, sehingga dapat disimpulkan bahwa faktor lain-lainnya diluar kontrol pemilik secara parsial berpengaruh secara signifikan dan negatif terhadap keterlambatan proyek.

Faktor-faktor yang menyebabkan keterlambatan waktu pelaksanaan proyek di lingkungan Perusahaan kontraktor DIY disebabkan oleh aspek perencanaan dan penjadwalan pekerjaan yaitu penetapan jadwal proyek yang amat ketat oleh pemilik, tidak lengkapnya identifikasi jenis pekerjaan yang harus ada, rencana urutan kerja yang tidak tersusun dengan baik/terpadu, penentuan durasi waktu kerja yang tidak seksama, rencana kerja pemilik yang sering berubah-ubah, metode konstruksi/pelaksanaan kerja yang salah atau tidak tepat. Dari aspek lingkup dan dokumen pekerjaan yaitu perencanaan (gambar/spesifikasi) yang salah/tidak lengkap, perubahan disain/detail pekerjaan pada waktu pelaksanaan, perubahan lingkup pekerjaan pada waktu pelaksanaan, proses pembuatan gambar kerja oleh kontraktor, proses permintaan dan persetujuan gambar kerja oleh pemilik, ketidaksepahaman aturan pembuatan gambar kerja, adanya banyak (sering) pekerjaan tambah, adanya permintaan perubahan atas pekerjaan yang telah selesai. Dari aspek sistem organisasi, koordinasi dan komunikasi yaitu keterbatasan wewenang personil pemilik alam pengambilan keputusan, kualifikasi personil/pemilik yang tidak profesional di bidangnya, cara inspeksi dan kontrol pekerjaan yang birokrasi oleh pemilik, kegagalan pemilik mengkoordinasi pekerjaan dari banyak kontraktor/sub kontraktor. Kegagalan pemilik mengkoordinasi

penyerahaan/pengunaan lahan, kelambatan penyediaan alat/bahan dll. yang disediakan pemilik, kualifikasi teknis dan manajerial yang buruk dari personil-personil dalam 
organisasi kerja kontraktor, koordinasi dan komunikasi yang buruk antar bagian-bagian dalam organisasi kerja kontraktor, terjadinya kecelakaan kerja. Dari aspek kesiapan/penyiapan sumber daya yaitu mobilisasi sumber daya (bahan, alat tenaga kerja) yang lambat, kurangnya keahlian dan keterampilan serta motivasi kerja para pekerja-pekerja langsung di tapak, jumlah pekerja yang kurang mamadai/sesuai dengan aktivitas pekerjaan yang ada, tidak tersedianya bahan secara cukup pasti/layak sesuai kebutuhan, tidak tesedianya alat/peralatan yang cukup memadai/ sesuai kebutuhan , kelalaian/keterlambatan oleh sub kontraktor pekerjaan, pendanaan kegiatan proyek yang tidak terencana dengan baik (kesulitan pendanaan di kontraktor), tidak terbanyarnya kontraktor secara layak sesuai haknya (kesulitan pembayaran oleh pemilik). Dari aspek sistem inspeksi, aspek kontrol dan evaluasi pekerjaan yaitu pengajuan bahan bahan oleh kontraktor yang tidak terjadwal, proses permintaan dan persetujuan contoh bahan oleh pemilik yang lama, proses pengujian dan evaluasi uji bahan dari pemilik yang tidak relevan, proses persetujuan ijin kerja yang bertele-tele, kegagalan kontraktor melaksanakan pekerjaan, banyak hasil pekerjaan yang harus diperbaiki/diulang karena cacat/tidak benar, proses dan tata cara evaluasi kemajuan pekerjaan yang lama dan lewat jadwal yang disepakati. Dari aspek lain-lainnya diluar kontrol pemilik yaitu kondisi dan lingkungan tanpak nyata tidak sesuai dengan dugaan, trasportasi ke lokasi proyek yang sulit, terjadinya hal-hal tak terduga seperti kebakaran, banjir, badai/angin ribut, gempa bumi, tanah longsor dan cuaca amat buruk, adanya kemogokan buruh, adanya huru/hara, terjadinya kerusakan/pengrusakan akibat kelalaian atau perbuatan pihak ketiga, perubahan situasi atau kebijaksanaan politik/ekonomi pemerintah. Apabila kontraktor dapat mengatasi masalah-masalah tersebut maka keberhasilan atau kesuksesan proyek dapat dicapai dengan baik.

\section{Kesimpulan}

Berdasarkan hasil analisis data diperoleh kesimpulan sebagai berikut:

1. Peringkat faktor-faktor yang menyebabkan keterlambatan waktu pelaksanaan proyek di lingkungan 
Perusahaan kontraktor DIY secara berurutan yaitu aspek lingkup dan dokumen pekerjaan, aspek sistem inspeksi, aspek kontrol dan evaluasi pekerjaan, sspek sistem organisasi, koordinasi dan komunikasi, aspek lain-lainnya diluar kontrol pemilik, aspek kesiapan/penyiapan sumber daya, dan aspek perencanaan dan penjadwalan pekerjaan. Faktorfaktor keterlambatan tersebut termasuk tinggi.

2. Faktor-faktor keterlambatan proyek yang terdiri dari aspek perencanaan dan penjadwalan pekerjaan, aspek lingkup dan dokumen pekerjaan, aspek sistem organisasi, koordinasi dan komunikasi, aspek kesiapan/penyiapan sumber daya, aspek sistem inspeksi, kontrol dan evaluasi dan aspek lain-lain diluar kendali pemilik berpengaruh secara simultan maupun parsial terhadap tingkat keterlambatan proyek di Dinas Pengairan dan Bina Marga lingkungan Perusahaan kontraktor DIY. Besarnya nilai pengaruh faktor-faktor keterlambatan proyek secara simultan ditunjukkan oleh nilai koefisien determinasi (R2) = 98,3\% yaitu persentase pengaruh faktor-faktor keterlambatan proyek yang terdiri dari aspek perencanaan dan penjadwalan pekerjaan, aspek lingkup dan dokumen pekerjaan, aspek sistem organisasi, koordinasi dan komunikasi, aspek kesiapan/penyiapan sumber daya, aspek sistem inspeksi, kontrol dan evaluasi dan aspek lain-lain diluar kendali pemilik terhadap perubahan tingkat keterlambatan proyek di dinas pengairan adalah sebesar 98,3\%. Variabel lain yang menjelaskan variasi perubahan tingkat keterlambatan proyek secara menyeluruh adalah sebesar $1,7 \%$.

\section{Saran}

Implikasi dari penelitian ini ada dua yaitu secara teoritis dan secara praktis. Secara teoritis, hasil penelitian ini menunjukkan bahwa faktor-faktor keterlambatan proyek yang terdiri dari aspek perencanaan dan penjadwalan pekerjaan, aspek lingkup dan dokumen pekerjaan, aspek sistem organisasi, koordinasi dan komunikasi, aspek kesiapan/penyiapan sumber daya, aspek sistem inspeksi, kontrol dan evaluasi dan aspek lain-lain diluar kendali pemilik berpengaruh secara 
negatif dan signifikan terhadap tingkat kesuksesan proyek. Sedangkan implikasi secara praktis, penelitian ini diharapkan dapat diimplementasikan oleh kontraktor dalam mempertimbangkan faktor-faktor keterlambatan proyek dalam meningkatkan kesuksesan proyek. Faktor-faktor keterlambatan proyek yang paling tinggi adalah aspek lingkup dan dokumen pekerjaan. Sehingga pihak kontraktor perlu melakukan perencanaan (gambar/spesifikasi) yang lengkap, meminimalisir perubahan disain/detail pekerjaan pada waktu pelaksanaan, perubahan lingkup pekerjaan pada waktu pelaksanaan, proses pembuatan gambar kerja oleh kontraktor, proses permintaan dan persetujuan gambar kerja oleh pemilik, ketidaksepahaman aturan pembuatan gambar kerja, perencanaan kerja sehingga menghindari adanya pekerjaan tambahan, dan perubahan atas pekerjaan yang telah selesai.

Penelitian ini tidak lepas dari beberapa keterbatasan dan kelemahan. Keterbatasan dalam penelitian ini berupa persepsi responden tergantung pada pemahaman butir pertanyaan yang tercantum dalam kuesioner sehingga kemungkinan terjadi perbedaan persepsi responden dengan pengukuran yang bersifat self reported.

Kelemahan dari penelitian ini yaitu penelitian ini hanya dilakukan survei melalui kuesioner tanpa dilengkapi dengan metode pengumpulan data lainnya untuk keakuratan data yang diteliti seperti wawancara. Peneliti memberikan saran agar metode pengumpulan data selanjutnya dapat dilengkapi dengan metode lainnya seperti wawancara agar data yang dikumpulkan lebih akurat dan menghindari perbedaan persepsi responden dengan pengukuran. Penelitian selanjutnya dapat juga mengembangkan perspektif yang diteliti lebih luas lagi misalnya perbedaan faktor-faktor keterlambatan berdasarkan ukuran atau size proyek konstruksi

\section{DAFTAR PUSTAKA}

Alhusin, Syahri. 2002, Aplikasi Statistik Praktis dengan SPSS.10 for Windows, Yogyakarta: J\&J Learning.

Arditi, D and Patel , BK, 1989 ." Impact Analsysis Of Owner-Directed 
Acceleration" Jurnal of

Construction Engineering and Managemen, ASCE Vol 115, no,1, ,pp.144-157.

Arditi, D Akan, GT. And Gurdamar, S. 1985. Reason for Delay in Public Projects in Turkey, Constrution Managemen and Economic Vol.3 Cooper, D.R. \& Emory, C.W. 1995, Business Research Methods, Fifth Edition, Chicago: Rhichard D. Irwin, Inc.

Dajan, Anto. 1998, Statistik I. Edisi 2. Jakarta: Tiga Serangkai

Elinwa, A.U. \& Buba, S.A. 1993, Construction Delay in Construction Projects, Journal of Construction Engineering and Management Atma Jaya, Yogyakarta

Kaming P.F. 1996. Causes of Construction Timr and Cost Overrus in Indonesia, Seminar Setu Pon, Faculty Of Engineering, Uneversitas Atma Jaya, Yogyakarta,

Kraiem, ZK. And Dickmann, JE. 1987. Concurrent Delays in Construction
Project, Jurnal of Construction Engineering and Managemen ASCE, vol.113 no.4 , pp.591-602.

Nicholas, JM. 1990. Managing Business and Engineering Project, PrenticeHall Inc.

Proboyo,

Budiman.1999.

Keterlambatan Waktu Pelaksanaan Proyek: Klasifikasi Dan Peringkat Dari PenyebabPenyebabnya. Dimensi Teknik Sipil Vol 1 Maret.

Soeharto, Iman. 1995. Manajemen Proyek: Dari Konseptual Sampai Operasional, Penerbit Erlangga: Yogyakarta, Edisi 1

Soeharto, Iman. 1999. Manajemen Proyek: Dari Konseptual Sampai Operasional, Penerbit Erlangga: Yogyakarta, Edisi 2

Sukanto, Reksohadiprojo. 1992. Manajemen Proyek. BPFE UGM: Yogyakarta. 